\title{
s. Anna Mroczek CSA, \\ Dobrego dnia z Aniotem Stróżem, Myśli na każdy dzień roku, Częstochowa 2013, 154 s.
}

Wiedza współczesnego człowieka, podobnie jak w przeszłości, inspiruje go do usprawniania rzeczywistości materialnej. Doświadczenie codzienne i możliwość weryfikacji dzięki niemu osiągnięć, utwierdza w przekonaniu o niepodważalnej wartości materialnego wymiaru świata i życia. Ostatnie lata pokazują, że w człowieku wieku XXI odrodziło się zainteresowanie także wymiarem duchowym. Najbardziej widać to po fascynacji światem aniołów. Człowiek żyjący we współczesnym świecie, zajmujący się różnymi profesjami interesuje się istotami duchowymi zarówno tymi dobrymi jak i złymi. Ów trend sprawia, że pojawia się coraz więcej literatury na ich temat. W poezji mamy różne motywy do nich nawiązujące. W sztukach teatralnych czy w filmach ich obecność jest coraz częstsza aż po świat przemysłowy i marketingowy, albowiem coraz więcej produkuje się figur ich przedstawiających.

Angeologiczna literatura cieszy się zainteresowaniem, a treści w niej zawarte są pomocą do pogłębienia wiedzy na ten temat. Aniołowie to istoty duchowe, o ich istnieniu informuje Biblia, pełnią one funkcje w relacji do Boga poprzez adorację i uwielbienie Go, natomiast w stosunku do człowieka, będąc posłańcami Boga, przekazującymi Jego Objawienie. Aniołowie zatem są pośrednikami ujawniającymi Bożą Opatrzność. Oprócz Biblii Starego i Nowego Testamentu źródłem nauki o aniołach i ich roli w historii Zbawienia są refleksje poświęcone angeleologii przez Ojców Kościoła jak też mistyków i teologów, czy wypowiedzi doktrynalne wyrażone przez Kościół mocą jego Urzędu Nauczycielskiego.

Książka s. Anny Mroczek Dobrego dnia z Aniołem Stróżem jest cenną pomocą w literaturze angeologicznej, gdyż wpisuje się w nurt zainteresowań współczesnego człowieka światem duchowym i jednocześnie umożliwia mu przeżywanie koegzystencji z Aniołem Stróżem poprzez 
refleksję sięgającą nauki Ojców Kościoła i współczesnych teologów przyczynia się do włączenia w codzienność Anioła Stróża i staje się ogromną pomocą w pogłębianiu życia duchowego pokazując na jego czynny udział w egzystencjalnym trudzie człowieka, uczynności, dobroci i duchowych zmaganiach, które kreślą rytm życia. Myśli o Aniele Stróżu, zebrane przez s. Mroczek i przyporządkowane poszczególnym dniom w roku prowadzą cierpliwie czytelnika do odkrywania fascynującej postaci Anioła Stróża, jak też przyczyniają się do ożywienia indywidualnej relacji osoby z Aniołem Stróżem. Czytelnik może napotkać na takie myśli, które przyjmie z prostotą serca, ale też i na takie, które zmuszą go do wnikliwszej analizy. Zarówno w jednym jak i w drugim przypadku na pewno pozostawią niezatarty ślad w jego świadomości przyczyniając się do jego duchowego wzrostu.

Zawarte w niej treści, zwłaszcza o służebnej roli Anioła Stróża

Sprawozdania i recenzje w życiu człowieka i we wspólnocie Kościoła są pomocą w drodze ukierunkowanej na odkrywanie ostatecznego sensu egzystencji ziemskiej w perspektywie eschatologicznej. Zadaniem Anioła Stróża jest wspierać człowieka w jego misji i życiowym powołaniu, ukierunkowując go na interpersonalną relację z Bogiem. Życie człowieka podobnie jak działanie Anioła Stróża ma służyć adoracji i wychwalaniu Boga Trójjedynego.

Książka jest zatem pomocą każdemu człowiekowi, którego zainteresowaniem jest personalna relacja z Bogiem. Powinna być udostępniona jak najszerszemu gronu czytelników szukających egzystencjalnego spełnienia i jedności w wierze. 